\title{
The impact of inadequate wastewater treatment on the receiving water bodies - Case study: Buffalo City and Nkokonbe Municipalities of the Eastern Cape Province
}

\author{
MNB Momba'* AN Osode ${ }^{2}$ and $M$ Sibewu ${ }^{1}$ \\ ${ }^{1}$ Tshwane University of Technology, Water Care Department, Arcadia Campus, P/Bag x 680 Pretoria 0002, South Africa \\ ${ }^{2}$ Department of Microbiology and Biochemistry, University of Fort Hare, P/Bag X1314, Alice 5700, South Africa
}

\begin{abstract}
The performance of four wastewater treatment plants that serve the Buffalo City (Dimbaza, East London) and Nkokonbe (Alice, Fort Beaufort) Municipal areas in the Eastern Cape Province of South Africa was investigated for the removal of microbial and chemical contaminants. Statistical evidence showed a relationship between the quality of the final effluent and that of the receiving water body and the relationship was such that the better the quality of the final effluent, the better the quality of the receiving water body. The quality of both the effluents and the receiving water bodies was acceptable with respect to the temperature (mean range: 16.52 to $23.33^{\circ} \mathrm{C}$ ), $\mathrm{pH}$ (mean range: 7.79 to 8.97 ), chemical oxygen demand (COD) (mean range: 7 to $20 \mathrm{mg} / \ell$ ) and total suspended solids (TSS) (mean range: 161.43 to $215.67 \mathrm{mg} / \ell$ ). However, in terms of the nutrients (orthophosphate - mean range: 3.70 to $11.58 \mathrm{mg} / \ell$ and total nitrogen - mean range: 2.90 to $6.90 \mathrm{mg} / \ell$ ) the effluents and the receiving water bodies were eutrophic. The dissolved oxygen (DO) (mean range: 3.26 to $4.57 \mathrm{mg} / \ell$ ) and the biological oxygen demand (BOD) (mean range: 14 to $24 \mathrm{mg} / \ell$ ) did not comply with the EU guidelines for the protection of the aquatic ecosystems. The general microbiological quality of the effluents discharged from all the plants did not comply with the limits set by the South African authorities in respect of pathogens such as Salmonella, Shigella, Vibrio cholera and coliphages. The effluents discharged from the Dimbaza, East London, Alice and Fort Beaufort wastewater treatment plants were identified as pollution point sources into their respective receiving water bodies (Tembisa Dam, the Nahoon and Eastern Beach which are part of the Indian Ocean; the Tyume River and the Kat River).
\end{abstract}

Keywords: wastewater, treatment, effluent, receiving water bodies, pollution

\section{Introduction}

South Africa is a water-scarce country, and the demands on this resource are growing as the economy expands and the population increases. For the country to continue to develop economically, while meeting the wide-ranging needs for water, urgent steps must be taken to protect the quality of the resource. It is well known that water sources are subjected to frequent dramatic changes in microbial and chemical qualities as a result of the variety of activities on the watershed. These changes are caused by discharges of municipal raw waters or treated effluent at a specific point-source into the receiving waters such as streams, rivers, lakes, ponds etc. (Gieldereich, 1990). Point-source pollution problems not only increase treatment costs considerably, but also introduce a wide range of potentially infectious agents to waters that may be supplied to many rural and urban communities, thus resulting in incidences of waterborne diseases with far reaching socio-economic implications (Craun, 1991).

Pathogens such as Shigella, Salmonella, Vibrio cholera and enteric viruses have been known to cause severe diarrhoea, in children and adults, which can lead to morbidity and mortality, as experienced in South Africa recently with outbreaks of Shigella dysenteriae and Vibrio cholera that resulted in 13 and 288 fatalities, respectively (Pegram et al., 1998; DPLG 2001). Also,

This paper was originally presented at the 2006 Water Institute of South Africa (WISA) Biennial Conference, Durban, South Africa, 21-25 May 2006.

* To whom all correspondence should be addressed.

罖+2712 382-6365; fax:+2712 382-6233; e-mail: mombamnb@tut.ac.za typhoid fever remains endemic to many parts of South Africa, including KwaZulu-Natal, Limpompo and the Transkei (Coovadia et al., 1992), with a recent outbreak occurring in Delmas, Mpumalanga. In this province, health spokespersons reported that there were 380 cases of diarrhoea, 30 suspected cases of typhoid fever and nine confirmed cases (Mail and Guardian, 2004). The outbreak originated in the town's water supply, suspected to have been contaminated with human faeces. Hepatitis A virus, caliciviruses, adenoviruses, rotavirus, and enteroviruses have the greatest effect on public health. A large number of epidemics due to the presence of these viruses in the environment have been reported (Anderson and Strenström, 1987; Yao, 1988; Bosch et al., 1991).

Wastewater treatment plants discharge significant amounts of faecal pollution indicators and pathogenic micro-organisms leading to a reduction in the quality of water (Bahlaoui et al., 1997; Simpson and Charles, 2000). The Buffalo City and Nkonkobe Municipalities of the Eastern Cape Province are obligated to provide safe drinking water, to address public health risks of polluted environmental water affecting the entire community, and to comply with stipulated standards. The poor operational state and inadequate maintenance of most of these municipalities' sewage treatment works, i.e. design weaknesses, overloaded capacity, faulty equipment and machinery, has resulted in major pollution problem and impacts on the quality of water resources, with marine water quality standards consequently not meeting regulatory standards. In this paper, we report the impacts of discharged effluents of some wastewater treatment plants located in the Eastern Cape Province of South Africa on their respective receiving water bodies. 


\section{Materials and methods}

\section{Study site}

Four wastewater treatment plants that serve the Buffalo City (Dimbaza and East London) and Nkonkobe (Alice and Fort Beaufort) Municipal areas in the Eastern Cape Province of South Africa were used in this study. The wastewater treatment plants are located in rural areas (Alice and Fort Beaufort Sewage Treatment Works), semi-urban (Dimbaza Sewage Treatment Works) and in urban (East Bank Reclamation Works) areas. The activated sludge system is the biological wastewater treatment used in all four plants, followed by chlorination of the final effluent. The Alice Wastewater Treatment Plant is situated on the banks of the Tyume River, which is also used as the receiving water body for the final effluent from the plant. The final effluent from the Fort Beaufort Sewage Works is discharged into the Kat River. The Dimbaza Wastewater Treatment Plant discharges its final effluent into a stream that empties into the Tembisa sewage dam. The final effluent from the East Bank Reclamation Works is discharged into the Indian Ocean between Nahoon and Eastern Beach at Bats Cave and into a pond for the irrigation of a nearby golf course. Supernatant liquor from the sedimentation tanks is channelled into a fishpond located within the plant premises.

Wastewater samples were collected between 6 August 2003 and 24 March 2004 and between the 25 October and 25 November 2004 from the raw influents, the final effluents and the receiving water bodies of the four plants. Samples for microbial analyses were aseptically collected in sterile $2 \ell$ glass bottles (for chlorinated final effluents, the sterile glass bottles contained $c .17 .5$ $\mathrm{mg} / \ell$ sodium thiosulphate). For chemical analyses, thoroughly cleaned non-sterile $2 \ell$ glass bottles were used according to the standard procedures described elsewhere (DWAF, 1992; DWAF, 1998). The samples were then placed in coolers containing ice packs and transported to the base laboratory at the University of Fort Hare for analyses within 2 to $4 \mathrm{~h}$ after collection.

\section{Physico-chemical analysis}

Temperature and $\mathrm{pH}$ were determined on site with a mercury thermometer and a pH meter, model 2000 (Crisson Instruments). The concentrations of free chlorine residual in the treated effluent samples were determined using a multi-parameter ion-specific meter (Hanna BDH-laboratory). The concentrations of orthophosphate as $\mathrm{P}$, total nitrogen (nitrate + nitrite as $\mathrm{N}$ ) and chemical oxygen demand (COD) were determined by the standard photometric method (DWAF, 1999) using the Spectroquant NOVA 60 photometer (Merck Pty Ltd). Samples for COD analyses were digested with a Thermo reactor Model TR 300 (Merck (Pty) Ltd) and then analysed by the Spectroquant NOVA 60 photometer (Merck Pty Ltd). Biochemical oxygen demand $\left(\mathrm{BOD}_{5}\right)$ was determined using the Oxitop WTW BOD meter (Merck (Pty) Ltd). The incubation period for BOD determinations was $5 \mathrm{~d}$. Dissolved oxygen (DO) was measured with the Merck DO meter, Model Ox 330 (Merck Pty Ltd) while total suspended solids (TSS) were estimated according to standard methods (DWAF, 1999).

\section{Microbiological analysis}

Raw influent, final effluent and receiving water body samples were analysed for the target micro-organisms using internationally accepted techniques and principles (14). The isolation of Salmonella and Shigella was done by enrichment in tetrathionate broth (Merck) in accordance with established method (DWAF, 1999). Isolation of Vibrio was done by enrichment in alkaline peptone broth $(\mathrm{pH} 8.5)$ for $6-8 \mathrm{~h}$ at $37^{\circ} \mathrm{C}$, after which the cultures were diluted and plated on Vibrio diagnostic agar (VDA) (Biolab) and incubated aerobically for $24 \mathrm{~h}$ at $37^{\circ} \mathrm{C}$ as described elsewhere (APHA, 1998).

For the coliphages analyses, wastewater samples were passed through filters ( $25 \mathrm{~mm}, 0.45 \mu \mathrm{m}$ Millipore filters) into sterile $250 \mathrm{~m} \ell$ flasks. The filters were pre-treated with $10 \mathrm{~m} \ell$ of sterile $1.5 \%$ beef extract to minimise phage adsorption to the filters. The filtrates were then serially diluted in antibiotic-free peptone-saline within the range of $10^{-1}$ to $10^{-5}$. Enumeration of somatic coliphages and F-RNA coliphages was done on double-agar-layer plaque assay (SABS, 2001) using E. coli strain C (ATCC 13706) nalidixic acid-resistant mutant WG5 and Salmonella typhimurium WG 49 nalidixic acid-resistant mutant as hosts respectively, and inoculum culture was prepared as described elsewhere (Grabow, 1996).

\section{Identification of bacterial isolates}

The individual bacterial colonies from the different stages of the wastewater treatment plants were randomly selected from various plates (XLD, VDA and Chromocult agar) and sub-cultured onto the corresponding recovery media. The colonies were further purified by the same method for at least three times using nutrient agar (Biolab) before Gram staining. Oxidase test was then conducted on those colonies that were gram negative. The API 20E kit was used for the oxidase-negative colonies and the strips were incubated at $37^{\circ} \mathrm{C}$ for $24 \mathrm{~h}$. The strips were then read and the final identification was secured using API LAB PLUS computer software (BioMérieux, Marcy l'Etoile, France).

\section{Results and discussion}

\section{Concentration of chlorine residual in the final effluent}

Table 1 illustrates the free chlorine residual concentrations in the final effluents of the wastewater treatment plants during the study period. Chlorine residual concentration ranged between 0.05 and $3.50 \mathrm{mg} / \ell$ throughout the sampling period, with overdosing observed during the months of August 2003 in Dimbaza and September 2003 in Fort Beaufort (Table 1). A regular acceptable concentration of free chlorine residual was noted in the East London plant while low concentrations were noted in Alice plant during the study period.

Although the 1996 South African Guidelines do not specify any standard for the concentration of free chlorine residual in the treated effluent, this study considered those for domestic water supplies which recommend ranges of 0.3 to $0.6 \mathrm{mg} / \ell$ as ideal free chlorine residual concentration and 0.6 to 0.8 $\mathrm{mg} / \ell$ as good free chlorine residual concentration with insignificant risk of health effects (Mooijiman et al., 2001). The mean concentration of the free chlorine residual in the final effluents complied with the $0.3 \mathrm{mg} / \ell$ recommended for domestic water supplies.

\section{Physico-chemical characteristics of the wastewater samples}

For all four wastewater treatment plants, the values obtained for COD, TSS, temperature, $\mathrm{pH}$ and total suspended solids in the effluents and receiving surface water bodies were well within the recommended limit of no risks (Figs. 1 and 2). 


\begin{tabular}{|c|c|c|c|c|}
\hline \multicolumn{5}{|c|}{$\begin{array}{c}\text { TABLE 1 } \\
\begin{array}{c}\text { Concentrations of free chlorine residual in the final effluents } \\
\text { during the sampling period (ranges and means) }\end{array}\end{array}$} \\
\hline \multirow{2}{*}{$\begin{array}{l}\text { Wastewater } \\
\text { treatment plant }\end{array}$} & \multicolumn{4}{|c|}{ Chlorine residual (mg/e) } \\
\hline & Ranges" & Means" & Range & Means ${ }^{*}$ \\
\hline Dimbaza & $0.53-3.50$ & 1.67 & $0.16-0.37$ & 0.31 \\
\hline East London & $0.19-0.67$ & 0.52 & $0.24-0.54$ & 0.37 \\
\hline Alice & $0.14-0.66$ & 0.29 & $0.24-0.39$ & 0.33 \\
\hline Fort Beaufort & $0.05-1.40$ & 0.49 & $0.32-0.48$ & 0.39 \\
\hline
\end{tabular}

Figure 1

Mean value of $C O D$ and TSS in the influent, effluent and the receiving water bodies of the individual wastewater treatment plants.

Figure 2

Mean values of temperature $\left({ }^{\circ} \mathrm{C}\right)$ and $\mathrm{pH}$ in the influent, effluent and the receiving water bodies of the individual wastewater treatment plants.
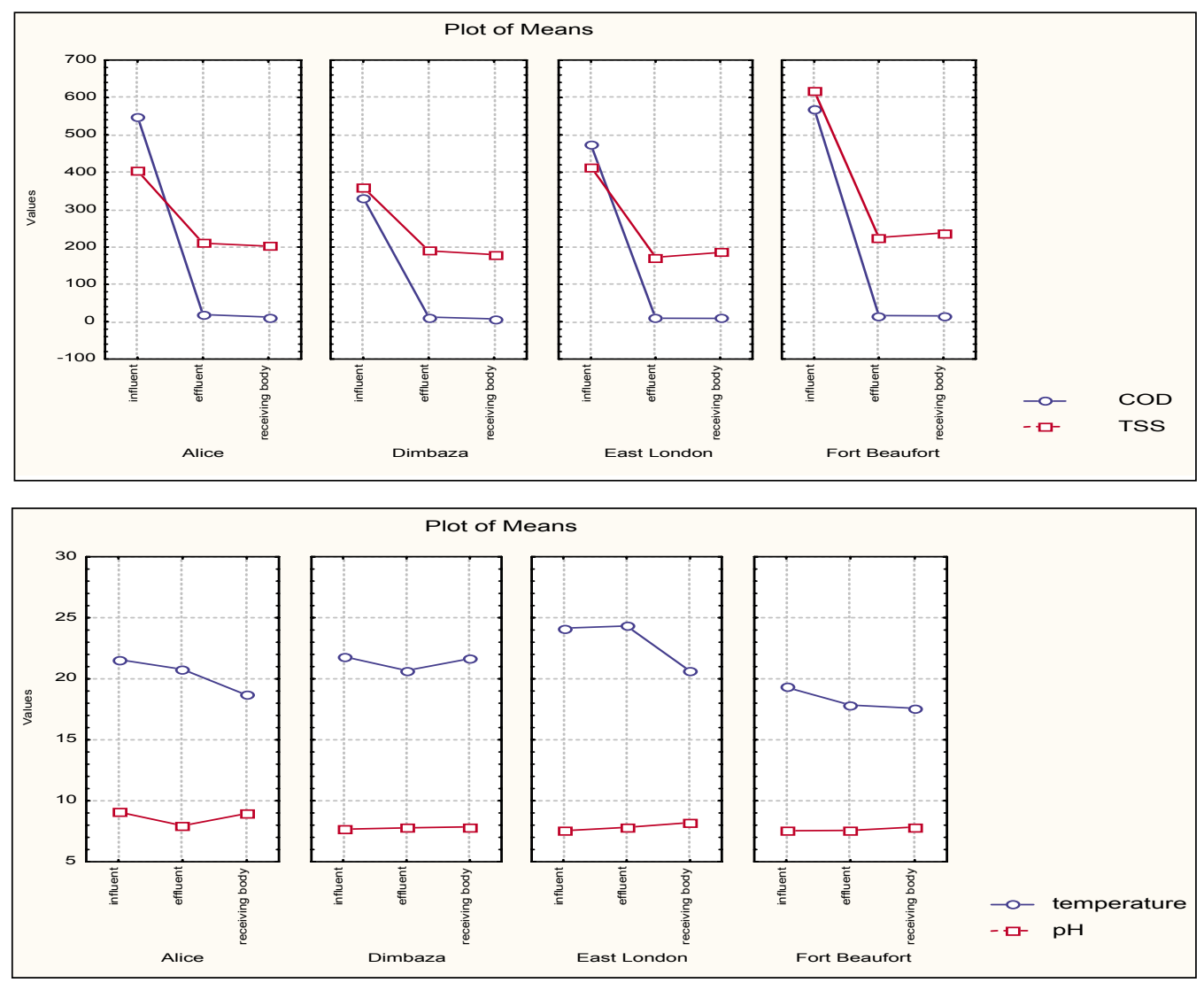

The BOD, DO, total nitrogen and phosphate concentrations are shown in Fig. 3. BOD indicates how much oxygen is needed by the water to completely oxidise its organic pollution load. There is no South African guideline for BOD in the effluent. For the protection of fisheries and the aquatic life, the EU guidelines stipulate the BOD target limits of 3.0 to $6.0 \mathrm{mg} / \ell$ (Chapman, 1996). The BOD levels recorded in all effluents and receiving water bodies are much higher than those indicated in the EU guidelines. Consequently the high levels of BOD in both effluents and receiving water bodies disqualify these water sources for use as aquatic ecosystems. Dissolved oxygen is an important parameter used for water quality control. The effect of waste discharge on a surface water source is largely determined by the oxygen balance of the system, and its presence is essential to maintaining biological life within a system (DFID, 1999). Dissolved oxygen concentrations in unpolluted water normally range between 8 and $10 \mathrm{mg} / \ell$ (Watson et al., 1985). Concentrations below 5 $\mathrm{mg} / \ell$ adversely affect aquatic life (DFID, 1999). The DO concentrations of the effluents and receiving water bodies (with the exception of the receiving water bodies in East London and Fort Beaufort) were less than $5 \mathrm{mg} / \ell$ (Fig. 2). Consequently, these water sources would not be suitable for use of aquatic ecosystems.

The mean total nitrogen (nitrate + nitrite as $\mathrm{N}$ ) levels showed a gradual decline from the influents to the effluents in each wastewater treatment (Fig. 3). However, the South African guidelines for total nitrogen (nitrate + nitrite as $\mathrm{N}$ ) in drinking water for domestic use is $<6.0 \mathrm{mg} / \ell$ as $\mathrm{N}$ (DWAF, 1998) and the target water quality range for total nitrogen in water for full contact recreational purpose is 6.0 to $10 \mathrm{mg} / \ell$ as $\mathrm{N}$. The World Health Organisation safe limit for nitrate for lifetime use is $10 \mathrm{mg} / \ell$ as $\mathrm{N}$. The total nitrogen levels obtained during the study period did not exceed the regulatory limits and thus total nitrogen is not considered to pose a problem to communities when the receiving water bodies are used for the domestic and recreational purposes. However, it is important to note that the total nitrogen levels in the final effluents could be a source of eutrophication for the receiving water bodies as the values obtained in all wastewater treatment plants (and especially in the Alice wastewater treatments) exceeded the recommended limits for no risk of 0 to $0.5 \mathrm{mg} / \ell$ as $\mathrm{N}$ (DWAF, 1996). 

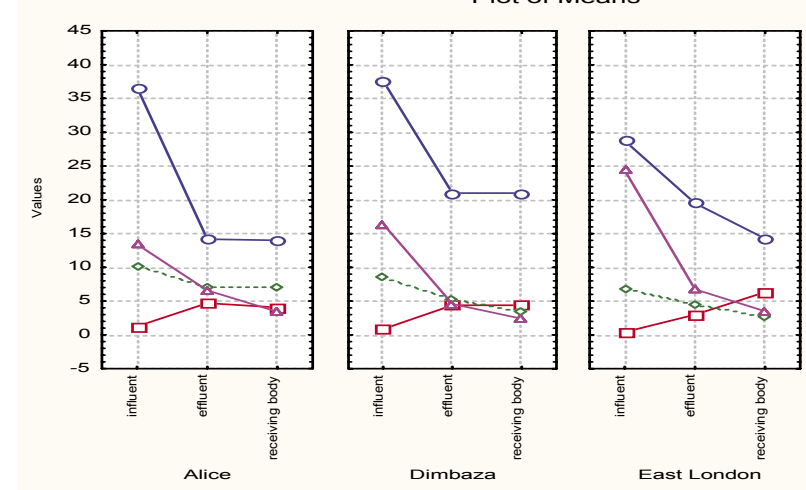

Although the levels of phosphate in influents varied from one plant to another, a gradual removal of phosphate was noted from the influent to the effluent in each wastewater treatment plant (Fig. 3). The mean levels of phosphate in effluents were $6.2 \mathrm{mg} / \ell$ in Alice, $5.4 \mathrm{mg} / \ell$ in Dimbaza, $5.9 \mathrm{mg} / \ell$ in East London and $11.6 \mathrm{mg} / \ell$ in Fort Beaufort. The levels of phosphate in receiving water bodies varied in accordance with those recorded in effluents (Fig. 3). In receiving water bodies, the levels of phosphate averaged in the range of 3.1 to $6.8 \mathrm{mg} / \ell$ (Fig. 3) and differ significantly $(\mathrm{p}<0.05)$ compared to the effluents as higher phosphate levels were found in effluent zones than in receiving water bodies. The South African guidelines do not specify the target water quality ranges for phosphate in water for domestic use and recreational purpose (DWAF, 1996). However the level of phosphate in water systems that will reduce the likelihood of algal and other plant growth is $5 \mu \mathrm{g} / \ell$ (DWAF, 1996). Other investigators have pointed out that eutrophication-related problems in temperate zones of aquatic systems begin to increase at ambient total $\mathrm{P}$ concentrations exceeding $0.035 \mathrm{mg} \mathrm{P} / \ell$. In warm-water systems, the values range between 0.34 and 0.70 $\mathrm{mg} \mathrm{P} / \ell(\mathrm{OECD}, 1982)$ and the associated $\mathrm{N}$ concentration would also range between 0.34 and $0.70 \mathrm{mg} \mathrm{N} / \ell$. These represent nutrient threshold levels beyond which there will be a corresponding increase in the risk and intensity of plant-related water quality problems (Nevondo and Cloete, 1999). Based on these limits (DWAF, 1996; OECD, 1982), the nutrient levels obtained in the present study are exceeded in both effluents and receiving water bodies. This is due to inadequate removal of nutrients by the Alice, Dimbaza, East London and the Fort Beaufort sewage treatment works. Their respective final effluent discharges are therefore considered as main sources of phosphate in Tyume River, Tembisa Dam, Nahoon and Eastern Beach (which are part of the Indian Ocean) and Kat River respectively.

\section{Microbiological characteristics of the wastewater samples}

In general, a gradual removal of presumptive bacterial pathogens was observed in the different zones of the wastewater treatment plants. Although, there were variations with regards to both the patterns and the efficiency of each plant for the removal of the target pathogens, about $71 \%$ of the total influent samples contained presumptive Salmonella, while only 50 and $33.5 \%$ of the effluent and receiving water body samples were observed to contain presumptive Salmonella (Fig. 4). Similar observations were made for presumptive Shigella and Vibrio pathogens with decreasing incidences of the pathogens from influents to the receiving water bodies (Fig. 4). The presence of these presump-

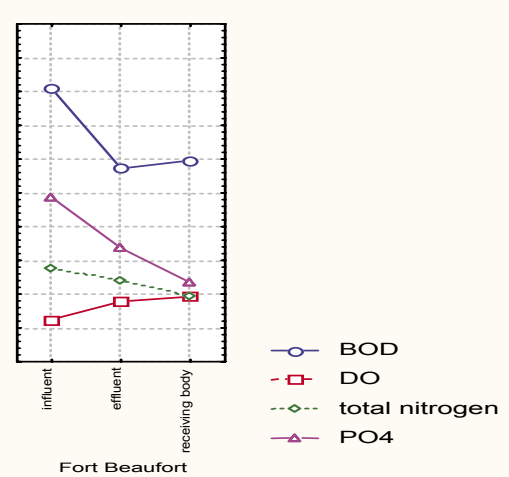

Figure 3

Mean values of $B O D$, $D O$, total nitrogen and phosphate in the influent, effluent and the receiving water bodies of the individual wastewater treatment plants

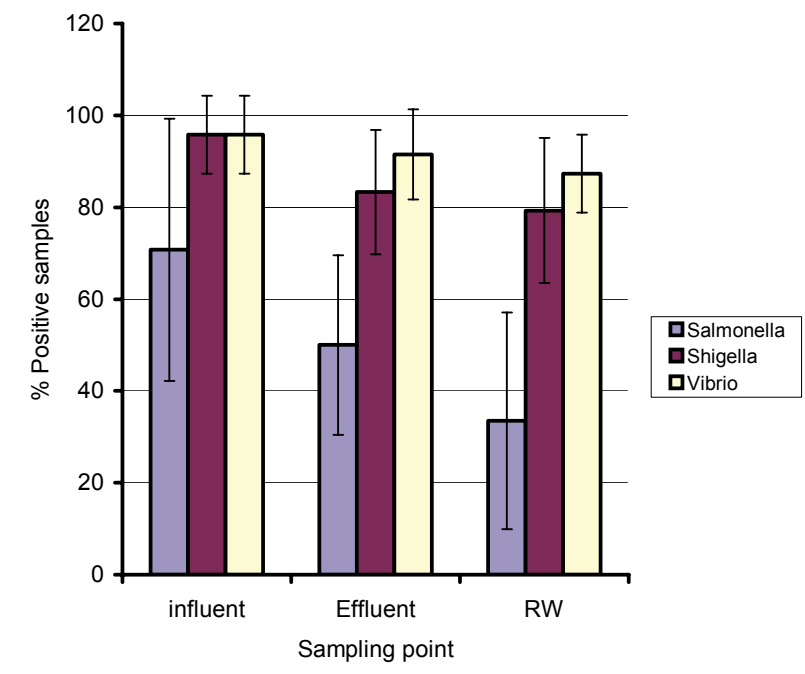

Figure 4

Cumulative proportions of the wastewater samples containing different presumptive bacterial pathogens

tive pathogens in the enriched cultures is indicative of the presence of at least one cell per $100 \mathrm{~m} \ell$ of the wastewater samples. Hence, the microbial qualities of the effluents in all locations exceeded the maximum safety limit for effluent discharge by the South African General and Special Standards of nil faecal coliforms $/ 100 \mathrm{~m} \ell$.

A total of 21 culturable bacterial species were identified in the wastewater samples. The number of species isolated from specific treatment stages in all the plants ranged between 6 and 10 (Table 2), but their distribution does not appear to follow any regular pattern. However, the presence of potential pathogens such as Aeromonas hydrophila and Escherichia coli in the effluent is a cause for concern as most people in the rural Eastern Cape region use these surface waters for drinking and recreational purposes. A previous report (Watson et al., 1985) has shown that the impact of waterborne diseases in the rural Eastern Cape Province of South Africa is significant as a result of drinking water sources with poor microbiological quality. The preponderance of $A$. hydrophila in the final effluents is an indication of the inefficiencies of the wastewater treatment plants for the removal of the presumptive pathogens, and a consequence of inadequate disinfection practices and inadequate maintenance of the infrastructure as suggested elsewhere (Pearson and Idema, 1998).

The four treatment plants contained high densities of both somatic and F-RNA coliphages. The densities of the somatic 


\begin{tabular}{|c|c|c|c|c|c|c|c|c|c|c|c|c|}
\hline \multicolumn{13}{|c|}{$\begin{array}{c}\text { TABLE } 2 \\
\text { List of bacteria species isolated from the treatment plants located at Alice, Dimbaza (DIM), } \\
\text { East London (E/London) and Fort-Beaufort (F/Beaufort) }\end{array}$} \\
\hline \multirow[t]{3}{*}{ Bacterial isolates } & \multicolumn{12}{|c|}{ Occurrence } \\
\hline & \multicolumn{3}{|c|}{ Alice } & \multicolumn{3}{|c|}{ Dim } & \multicolumn{3}{|c|}{ E/London } & \multicolumn{3}{|c|}{ F/Beaufort } \\
\hline & In & Eff & Rw & In & Eff & Rw & In & Eff & Rw & In & Eff & Rw \\
\hline Aeromonas hydrophilia & $\sqrt{ }$ & $\sqrt{ }$ & $\sqrt{ }$ & $\sqrt{ }$ & $\sqrt{ }$ & $\sqrt{ }$ & $\sqrt{ }$ & & $\sqrt{ }$ & $\sqrt{ }$ & & \\
\hline Aeromonas salmonicida & & & & & & & $\sqrt{ }$ & $\sqrt{ }$ & & & & \\
\hline Enterobater aerogenes & $\sqrt{ }$ & $\sqrt{ }$ & & $\sqrt{ }$ & $\sqrt{ }$ & & $\sqrt{ }$ & & & & & \\
\hline Enterobater cloacae & $\sqrt{ }$ & $\sqrt{ }$ & $\sqrt{ }$ & $\sqrt{ }$ & & $\sqrt{ }$ & $\sqrt{ }$ & $\sqrt{ }$ & $\sqrt{ }$ & $\sqrt{ }$ & $\sqrt{ }$ & $\sqrt{ }$ \\
\hline Escherichia coli & $\sqrt{ }$ & $\sqrt{ }$ & $\sqrt{ }$ & & & & & & & $\sqrt{ }$ & $\sqrt{ }$ & \\
\hline Klebsiella pneumoniae & $\sqrt{ }$ & $\sqrt{ }$ & $\sqrt{ }$ & $\sqrt{ }$ & $\sqrt{ }$ & $\sqrt{ }$ & $\sqrt{ }$ & $\sqrt{ }$ & $\sqrt{ }$ & & & $\sqrt{ }$ \\
\hline Klebsiella ozoenae & & & & $\sqrt{ }$ & $\sqrt{ }$ & & & & & & & \\
\hline Klebsiella oxytoca & & & & & & & $\sqrt{ }$ & $\sqrt{ }$ & & & & \\
\hline Klebsiella ornithinolytica & & & & & & & $\sqrt{ }$ & $\sqrt{ }$ & $\sqrt{ }$ & & & \\
\hline Morganella morganii & $\sqrt{ }$ & $\sqrt{ }$ & $\sqrt{ }$ & $\sqrt{ }$ & & & & & & $\sqrt{ }$ & $\sqrt{ }$ & \\
\hline Pasteurella pneumoniae & & & & & & & & & & $\sqrt{ }$ & $\sqrt{ }$ & $\sqrt{ }$ \\
\hline Proteus mirabilis & $\sqrt{ }$ & $\sqrt{ }$ & & $\sqrt{ }$ & $\sqrt{ }$ & $\sqrt{ }$ & $\sqrt{ }$ & $\sqrt{ }$ & $\sqrt{ }$ & $\sqrt{ }$ & $\sqrt{ }$ & $\sqrt{ }$ \\
\hline Providencia rettgeri & $\sqrt{ }$ & $\sqrt{ }$ & & $\sqrt{ }$ & $\sqrt{ }$ & $\sqrt{ }$ & $\sqrt{ }$ & $\sqrt{ }$ & & $\sqrt{ }$ & $\sqrt{ }$ & $\sqrt{ }$ \\
\hline Pseudomonas fluorescens & & & $\sqrt{ }$ & & & $\sqrt{ }$ & $\sqrt{ }$ & & $\sqrt{ }$ & & & \\
\hline Salmonella spp. & $\sqrt{ }$ & & & $\sqrt{ }$ & & & $\sqrt{ }$ & $\sqrt{ }$ & $\sqrt{ }$ & $\sqrt{ }$ & $\sqrt{ }$ & $\sqrt{ }$ \\
\hline Serratia liquifaciens & $\sqrt{ }$ & & & $\sqrt{ }$ & & & & & & & & \\
\hline Serratia odorifera & $\sqrt{ }$ & $\sqrt{ }$ & & & & & & & & & & \\
\hline Serratia plymithica & & & & & & & & & $\sqrt{ }$ & & & \\
\hline Shewan putrifaciens & & & & & & & & & & $\sqrt{ }$ & & \\
\hline Kluyvera spp. & & & & & & $\sqrt{ }$ & & & & & & \\
\hline Vibrio parahaemolyticus & & & & & & & $\sqrt{ }$ & & & & & $\sqrt{ }$ \\
\hline TOTAL & 11 & 9 & 6 & 10 & 6 & 7 & 12 & 8 & 8 & 9 & 7 & 7 \\
\hline
\end{tabular}

Figure 5

Performance of the different wastewater treatment plants for the removal of the somatic and F-RNA coliphages during the study period between 25 October and the 25 November 2005.

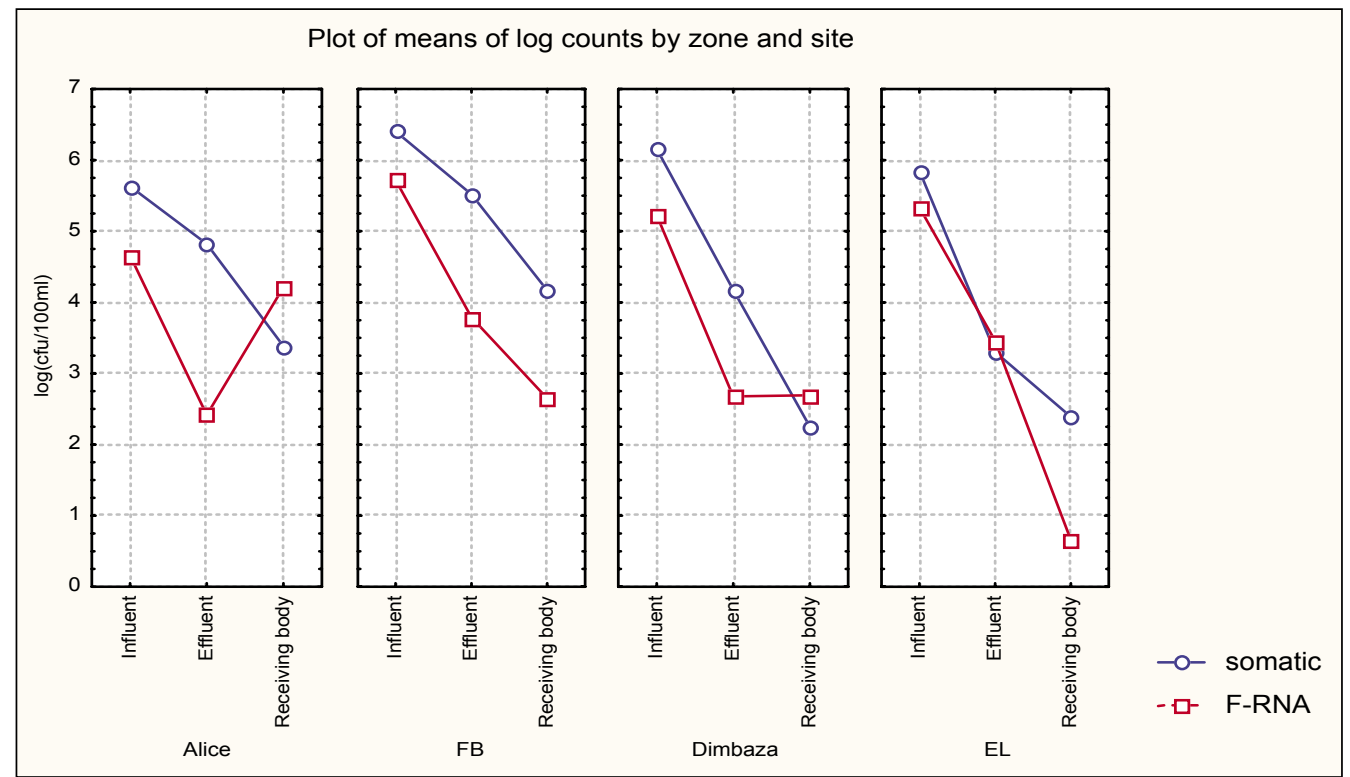

coliphages in the influent samples ranged between $5.6 \log _{10}$ to $6.5 \log _{10} \mathrm{pfu} / 100 \mathrm{~m} \ell$, being least at the East London plant and highest at the Alice plant. Treatment processes reduced the somatic coliphages densities in all treatment plants to between $3.2 \log _{10}$ and $5.5 \log _{10} \mathrm{pfu} / 100 \mathrm{~m} \ell$ in the effluents (Fig. 5), with the $\%$ reduction $\left(\log _{10}\right)$ being $28.1,13.5,31$ and $41 \%$ for Alice, Fort Beaufort, Dimbaza and East London plants respectively. A further reduction in somatic coliphages densities was observed at all receiving water bodies, and is probably a consequence of the dilution effect of the receiving water bodies. It would appear that the East London plant was most efficient in the removal of somatic coliphages.

F-RNA coliphages densities were generally lower than those of the somatic coliphages, and ranged between $4.7 \log _{10}$ and 5.8 $\log _{10}$ pfu/100 $\mathrm{m} \ell$ (Fig. 5) in the influents, amounting to reductions by approximately 48, 33, 48.3 and $35 \%$ for Alice, Fort Beaufort, Dimbaza and East London plants respectively. The F-RNA coliphages densities in the receiving water bodies 
followed a similar trend as the somatic coliphages, except for the Alice plant sample where it was higher than the effluent, a phenomenal indication of contamination from other source outside the treatment plant system.

\section{Conclusion}

Although the treatment plants succeeded in removing some presumptive pathogens from the influents, effluent discharges were only occasionally devoid of the organisms, thus constituting a potential threat of incidences of infectious diseases. Pearson and Idema (1998) had reported that in many cases in developing countries, a high level of reliability of water supply schemes, particularly the treatment process, is the exception rather than the rule, and that various factors such as cost, operator training and problems with maintenance of infrastructure could contribute to these problems. The current disinfection practices and guidelines in terms of chlorine residuals were found not to be sufficient for the removal of the target pathogens since high levels could still be detected in the final effluent. The inefficiency of all four wastewater treatment plants for the removal of somatic and F-RNA coliphages from their final effluents had a negative effect on the viral quality of receiving water bodies, although there might be other sources of faecal pollution. A case is made for a more stringent surveillance of the performances of wastewater treatment facilities in the Eastern Cape Province of South Africa, in order to ensure compliance with stipulated standards.

\section{Acknowledgement}

The authors wish to thank the National Research Foundation of South Africa who sponsored this investigation. The assistance of Dr A Okoh of the Department of Biochemistry and Microbiology and Mr A Mandeya of the Department of Statistics, Fort Hare University is also gratefully acknowledged.

\section{References}

ANDERSON Y and STRENSTRÖM A (1987) Waterborne outbreaks in Sweden: Causes and etiology. Water Sci. Technol. 19 (3) 75-580.

BAHLAOUI MA, BALEUX B and TROUSSELLIER M (1997) Dynamics of pollution-indicators and pathogenic bacteria in high rate oxidation wastewater treatment ponds. Water Res. 31 (3) 574-582.

BOSCH A, LUCENA F, DIEZ JM, GAJARDOR, BLASI M and JOFRE (1991) Waterborne viruses associated with hepatitis outbreak. J. Am. Water Works. Assoc. 83 (3) 80-83.

CHAPMAN D (1996) Water Quality Assessments (2 ${ }^{\text {nd }}$ edn.) Published by E. \& FN Spon, London.

COOVADIA YM, GATHIRAM V, BHAMJEE A, GARRATT RM, MLISANA K, PILLAY N, MADLALOSE T and SHORT M (1992) An outbreak of multiresistant Salmonella typhi in South Africa. $Q$. J. Med. 82 (2) 91-100.

CRAUN GF (1991) Cause of waterborne outbreaks in the United States Water Sci. Technol. 24 (2) 17-20.

DEPARTMENT OF PROVINCIAL AND LOCAL GOVERNMENT (2001) National Status Report on Cholera Epidemic in South
Africa http://sandmc.pwv.gov.za/ndmc/cholera (Accessed on 10/06/2005)

DEPARTMENT OF WATER AFFAIRS and FORESTRY (DWAF) (1996) South African Water Quality Guidelines (2 ${ }^{\text {nd }}$ edn.) Vol. 2: Domestic Use. Pretoria, RSA.

DFID (1999) A Simple Methodology for Water Quality Monitoring. HR report OD 142 (KAR Project R6662). In: Pearce GR, Chaudhry MR and Ghulum S (eds.) Published by the Department for International Development, Wallingford.

DWAF (DEPARTMENT OF WATER AFFAIRS AND FORESTRY) (1992) Analytical Methods Manual, TR 151. Pretoria, RSA.

DWAF (DEPARTMENT OF WATER AFFAIRS AND FORESTRY), DOH (DEPARTMENT OF HEALTH) AND WRC (WATER RESEARCH COMMISSION) (1998) Quality of Domestic Water Supplies Volume 1: Assessment Guide (2 ${ }^{\text {nd }}$ edn.) WRC Report No TT 101/98. ISBN No: 186845416 9. Water Research Commission, Pretoria, RSA.

DWAF (DEPARTMENT OF WATER AFFAIRS AND FORESTRY), DOH (DEPARTMENT OF HEALTH) AND WRC (WATER RESEARCH COMMISSION) (1999) Quality of Domestic WaterSupplies. Volume 2: Sampling Guide. WRC Report No TT 117/99. Water Research Commission, Pretoria, RSA.

GELDEREICH EE (1990) Microbiology quality of source waters for water supply. In: McFeters GA (ed.) Drinking Water Microbiology: Progress and Recent Development). Springer Verlag, New York. 3-31.

GRABOW WOK (1996) Waterborne disease: Update on water quality assessment and control. Water SA 22 (2) 193-202.

MAIL AND GUARDIAN (2005) Officials work to curb Delmas typhoid outbreak. Johannesburg, South Africa, 8 September.

MOOIJIMAN KA, BAHAR M, CONTRERAS N and HAVELAAR AH (2001). Optimisation of the ISO-method on enumeration of somatic coliphages. Water Sci.Technol. 23 (12) 205-208.

NEVONDO TS and CLOETE TE (1999) Bacterial and chemical quality of water supply in the Dertig village settlement Water SA 25 (2) 215-220.

OECD (1982) Eutrophication of Waters: Monitoring, Assessment and Control. Technical Report, Organization for Economic Cooperation and Development, Paris.

PEARSON I and IDEMA G (1998) CSIR Division of Water, Environment and Forestry Technology, Pretoria. WRC Report No 649/1/98. Water Research Commission, Pretoria, South Africa. 1-17.

PEGRAM GC, ROLLINS N and ESPREY Q (1998) Estimating the cost of diarrhoea and epidemic dysentery in Kwazulu-Natal and South Africa. Water SA 24 (1) 11-20.

SABS SB 1315 (2001) Water Quality - Detection and Enumeration of Vibrio cholera. South African Bureau of Standards ( $\left.1^{\text {st }} \mathrm{edn}\right)$.

SIMPSON E and CHARLES K (2000) The health threat posed to surrounding community by effluent discharged from rural hospital sewage treatment plants. Proc. WISA 2000 Conference, Sun City South Africa. 28 May - 1 June.

STANDARD METHODS (1998) Standard Methods for the Examination of Water and Wastewater (20 $0^{\text {th }}$ edn.). Clesceri LS, Greenberg AE and Eaton DA (eds.) American Public Health Association Washington, DC.

WATSON IM, ROBINSON JO, BURKE V and GRACE M (1985) Invasive of Aeromonas spp. In relation to biotype virulence factors and clinical features. J. Clin. Microbiol. 22 (1) 48-51.

YAO GB (1989) Clinical and natural history of hepatitis A in an epidemic in Shanghai. Proc. 1988 Int.Symp. on Viral Hepatitis and Liver Disease. Washington D.C. USA October 26-28. 